\title{
FURTHER COMMENT ON THE NOMENCLATURE OF THE FRESHWATER STINGRAY ELIPESURUS SPINICAUDA SCHOMBURGK, 1843 (CHONDRICHTHYES: POTAMOTRYGONIDAE)
}

RICARDO S. ROSA

\section{ABSTRACT}

The monotypic genus Elipesurus of neotropical freshwater stingrays, and its type species E. spinicauda, are known from a single specimen which lacked a developed tail and caudal sting. No type or similar specimens exist. The original description and illustration are inaccurate, without diagnostic measurements or characters, excepting those mentioned above. Therefore, a precise identification of $\mathrm{E}$. spinicauda remains impossible, and both names are considered doubtful. Since all other potamotrygonid stingrays have more or less developed tails and stings, the Elipesurus condition is regarded as a mutilation.

\section{INTRODUCTION}

The monotypic genus Elipesurus of South American freshwater stingrays was established by Schomburgk (1843). The type species, E. spinicauda, was based on a single and probably mutilated specimen from Rio Branco, Brazil (Garman, 1877, 1913; Vaillant, 1880; Eigenmann \& Eigenmann, 1891; Castex, 1964, 1968, 1969; Bailey, 1969). The generic and specific diagnoses were based on the presence of a very short tail, and the lack of the caudal sting normally found in other species of the family. Numerous spines were present at the base of the tail.

The specimen of E. spinicauda apparently was never sent to European museums, nor was found elsewhere. No type is known, and no similar specimens have been collected since the original description. Therefore, the generic and specific identities have remained uncertain (Castex, 1964, 1968). As explained below, Elipesurus and E. spinicauda are nomina dubia, and should be accordingly rejected.

\section{TAXONOMIC HISTORY}

Duméril (1865) emended Elipesurus to Ellipesurus, and was followed by Günther (1870), Eigenmann \& E'genmann (1891), and Ribeiro (1907). Garman (1913) improperly included Trygon strogylopterus Schomburgk, 1843 in the genus Elipesurus. Castex (1966) mistakenly considered E. spinicauda as a nomen oblitum. Castex (1968) proposed the suppression of the binomen for the purposes of the Law of Priority (relative to Potamotrygon Garman, 1877), and its placement on the Official Index of Rejected and Invalid Names in Zoology. Bailey (1969) reviewed these proposals and other items in Castex's paper, and concluded that E. spinicauda was a senior synonym of Disceus thayeri Garman, 1913. Two wrong statements by Castex (1968, statements 2 and 4) escaped Bailey's criticism: Paratrygon Duméril, 1865 was not a redes. cription of Elipesurus, nor was based on Raja ajereba Walbaum, 1792; Elipesurus was firstly emended to Ellipesurus by Duméril (1865), and not by Günther (1870). Most of Bailey's arguments against the rejection of Elipesurus were effectively criticized in a reply by Castex (1969), but they deserve further comment.

Departamento de Sistemática e Ecologia, CCEN, Universidade Federal da Paraíba, Cidade Universitária, 58000 João Pessoa, PB. 
1. Elipesurus spinicauda was not well illustrated and described. The short descriptive accounts of the genus and species were not sufficiently diagnostic, and disc length and width were the only measurements given. Schomburgk's illustrations were made in Europe from field sketches, and probably had errors in proportions and coloration (Eigenmann, 1912; Böhlke et al., 1978).

2. Elipesurus spinicauda is not equal to Disceus thayeri. Proportional measurements and other observations made by the present author on twentythree specimens of $D$. thayeri, including the syntypes, differ substantially from the description of E. spinicauda. The crucial relative morphometrics are the procular length and the eye diameter, which in Disceus are respectively larger and smaller than in Elipesurus. Small eyes, far removed from the snout, are not seen in the illustration of E. spinicauda, nor mentioned in its description. The color patterns of the two nominal species are also different from each other. All $D$. thayeri observed in this study, including freshly preserved specimens, were brown and not yellow, and lacked the reticulation seen in E. spinicauda. The presence of strong spines at the base of the tail is not decisive for synonymizing the two species, because specimens of $D$. thayeri may lack them, and because several species of the genus Potamotrygon may have these spines. The absence of an anterior median prominence on the disc, and the coverage of the pelvic fins by the disc, are similarly irrelevant. The former character is never greatly developed in any species of the family. Sometimes the prominence is missing or folded downward, and could be easily overlooked. Covered pelvic fins occur also in other species of the family, and vary depending on sex and conditions of fixation.

3. Disceus thayeri does not undergo notable changes in morphometrics and color with age. The tail and eyes are the only structures that show considerable allometry, the major diagnostic morphometrics being stable with growth. Slight variations of color are found in all ontogenetic stages, due to differences in pigment distribution.

4. The placement of $T$. strogylopterus in the synonymy of E. spinicauda is implausible, because the respective descriptions and illustrations do not correspond with respect to diagnostic characters, proportional measurements, and coloration.

5. I agree with Bailey in that $T$. strogylopterus is a synonym of $D$. thayeri. Some of the diagnostic characters of the latter species are represented in Schomburgk's illustration of T. strogylopterus. A spiracular prominence is present, the tail tapers abruptly behind the sting, and the coloration resembles that of $D$. thayeri. The synonymy of these two species was supported by Castex \& Castello (1969), who rediscovered the type specimen of T. strogylopterus in Berlin, and concluded that it was identical to D. thayeri. Examination of a radiograph and photographs of this type specimen by the present author corroborated this synonymy.

6. Potamotrygon brachyura (Günther, 1880) is presently unknown from the Amazon basin as Bailey (1969) remarked, therefore its synonymy with E. spinicauda, suggested by Castex $(1968,1969)$, is uncertain. Castex's (1966) statement that $P$. brachyura is found in the Amazon is doubtful, and probably based on mis-identified specimens. Furthermore, the reticulations in the color pattern of $P$. brachyura are larger than those seen in the illustration of $E$. spinicauda. The Amazonian species Potamotrygon orbignyi (Castelnau, 1855) and $P$. humerosa (Garman, 1913) have reticulation patterns similar to $E$. spinicauda, but this character alone is insufficient for their synonymization.

Referring to Castex's (1969) reply, I agree with objections (1) to (6), and partially with (9) and (10). The difference in the color patterns (9) of $E$. spinicauda and $P$. brachyura was already mentioned. From the position of the eyes (10) seen in Schomburgk's illustrations, E. spinicauda is clearly different from $D$. thayeri, but $T$. strogylopterus has an intermediate condition 
between Disceus and Potamotrygon. Comment (7) is false because a cut-off tail normally assumes a blunt end, and not the pointed condition seen in the illustration of E. spinicauda, where it was probably misrepresented. Tail denticles and spines usually tend to increased development in cut-off tails.

\section{DISCUSSION}

Garman's (1913) placement of T. strogylopterus in the genus Elipesurus was inadequate, because that species had the caudal sting and spiracular process, contradicting the diagnostic characters of Elipesurus (see Garman's key to the genera). Garman himself considered questionable his identification of T. strogylopterus, and added that the species could even belong to the genus Disceus, as he originally had proposed in 1877. When Garman (1913) redescribed D. strogylopterus, presumably as the new species $D$. thayeri, he needed a new generic placement for $T$. strogylopterus. The later species was clearly distinct from all Potamotrygon, therefore the only possible combination was with Elipesurus, since Garman did not recognize Paratrygon as a valid genus. Regarding E. spinicauda, Garman (1913) pointed that it had large eyes anteriorly positioned, and therefore differed from Disceus, where the opposite states of these characters are found, and represent important diagnostic features.

Several authors (Vaillant, 1880; Eigenmann \& Eigenmann, 1891; Garman, 1913; Devicenzi \& Teague, 1942; Castex, 1964, 1968, 1969) regarded E. spinicauda as a doubtful or provisional name. Among recent authors, only Ribeiro (1907), Fowler (1948, 1970), and Bailey (1969) considered Elipesurus valid, each one with a different taxonomic connotation. The tentative identifications of E. spinicauda from the original description (Ribeiro, 1907; Garman, 1913; Castex, 1964, 1968, 1969; Bailey, 1969) resulted in a confusing synonymy, including Potamotrygon dumerilii, $P$. motoro, $P$. brachyura, $P$. brumi, and Disceus thayeri. The description and illustration of E. spinicauda do not contain enough diagnostic characters to permit its association with any of these species, nor with any other species of the family Potamotrygonidae. Therefore, the name should not be used to imply D. thayeri and its synonyms, nor any of the species of the genus Potamotrygon.

Adult specimens of Potamotrygonidae usually lack the distal portions of their tails, and sometimes lack the caudal sting. The various explanations for this fact include serrasalmid fish bites and human action. Schomburgk himself mentioned that the indians used to cut off stingray tails, to obtain the stings which they used as arrow heads. An accidental or teratological loss of the tail and sting is the most plausible explanation for the absence of these structures in the specimen of E. spinicauda. Therefore, it is not reasonable to consider valid a genus and species established to include stingrays lacking developed tails and caudal sting.

\section{CONCLUSIONS}

Elipesurus was unwarrantably established for a teratologic or mutilated specimen, by a poor description and a probably inaccurate illustration, without type designation. Elipesurus, its emendation Ellipesurus, and the binomen E. spinicauda are herein considered nomina dubia. Therefore, the question of priority is moot, and these names do not require suppression, as requested by Castex (1968, request 1). The International Comission on Zoological Nomenclature should support all the other requests of Castex (1968, requests 2 to 6), with the correction of the gender of Potamotrygon in request (2), as suggested by Bailey (1969), the observation that the spelling Trygon histrix Müller \& Henle in: d'Orbigny, 1834 has priority over Trygon hystrix Müller \& Henle, 1841 in request (2), and the correction of the publication date of Potamotrygon and Potamotrygonidae (1877 instead of 1878) in request (6). 


\section{ACKNOWLEDGMENTS}

I thank W. L. Fink (formerly at Museum of Comparative Zoology, Harvard University, $\mathrm{MCZ}$ ) and $\mathrm{K}$. Hartel (MCZ) for loaning the syntypes of D. thayeri; Dr. H.-J. Paepke (Zoologisches Museum der Humboldt Universität, Berlin) and H. P. Castello (Museo Argentino de Ciencias Naturales Bernardino Rivadavia) for sending photographs and a radiograph of the type of T. strogylopterus.

I also thank Drs. R. M. Bailey (University of Michigan Museum of Zoology), R. V. Melville, Secretary of the International Comission on Zoological Nomenclature (British Museum, Natural History), T. B. Thorson (University of Nebraska-Lincoln), S. H. Weitzman (U. S. National Museum of Natural History), John D. McEachran (Texas A \& M University), J. A. Musick (Virginia Institute of Marine Science, VIMS), and K. J. Sulak (VIMS) for their comments on the manuscript. This study was supported by a grant from CAPES, Ministério da Educação e Cultura do Brasil.

\section{REFERENCES}

Bailey, R. M., 1969. Comment on the proposed suppression of Elipesurus spinicauda Schomburgk (Pisces) Z. N. (S.) 1825. Bull. zool. Nomencl. 25(4-5): 133-134.

Böhlke, J. E., S. H. Weitzman \& N. A. Menezes, 1978. Estado atual da sistemática dos peixes de água doce da América do Sul. Acta amaz. 8(4): 657-677.

Castelnau, F. L., 1855. Animaux nouveaux ou rares recueillis pendant l'expédition dans les parties centrales de l'Amérique du Sud, de Rio de Janeiro à Lima, et de Lima au Para. P. Bertrand, Paris 2: 112 pp., 50 pls.

Castex, M. N., 1964. Estado actual de los estudios sobre la raya fluvial neotropical. Rev. Mus. Prov. cienc. nat. F. Ameghino, no. cincuentenario: 9-49.

Castex, M. N., 1966. Observaciones en torno al genero Elipesurus Schomburgk 1843 y nueva sinonimia de Potamotrygon brachyurus (Günther, 1880) (Chondrichthyes, Potamotrygonidae). Physis 26(71): 33-38.

Castex, M. N., 1968. Elipesurus Schomburgk 1843 (Pisces): proposed suppression under the plenary powers. Z. N. (S) 1825. Bull. zool. Nomencl. 24(6): 353-355.

Castex, M. N., 1969. Comments on the objetions forwarded by R. M. Bailey to the proposed suppression of Elipesurus spinicauda Schomburgk (Pisces) Z. N. (S.) 1825. Ibidem 26(2): 68-69.

Castex, M. N. \& H. P. Castello, 1969. Nuevas sinonimias para el genero monotipico Disceus Garman 1877 (Potamotrygonidae) y observaciones sistemáticas a la familia Paratrygonidae Fowler 1948 (dubit.). Acta Scient. latinoam. Fisiol. Reprod. (7): 1-43.

Devicenzi, G. J. \& G. W. Teague, 1942. Ictiofauna del Uruguay medio. An. Mus. hist. nat. Montevideo, ser. 2, 5(4): 1-103.

Duméril, A., 1865. Histoire naturelle des poissons ou ichthyologie générale. Élasmobranches plagiostomes et holocéphales ou chimères. Paris.

Eigenmann, C. H., 1912. The freshwater fishes of British Guiana, including a study of the ecological grouping of species and the relation of the fauna of the plateau to that of the lowlands. Mem. Carnegie Mus. 5(1): 1-578.

Eigenmann, C. H. \& R. S. Eigenmann, 1891. A catalogue of the fresh-water fishes of South America. Proc. U. S. Nat. Mus. 14: 1-81.

Fowler, H. W., 1948. Peixes de água doce do Brasil. Arqos Zool. Est. S Paulo 6: 1-204.

Fowler, H. W., 1970. A catalog of world fishes (XII). Quart. J. Taiwan Mus. 23(1-2): 39-126.

Garman, S. W., 1877. On the pelvis and external sexual organs of selachians, with special reference to the new genera Potamotrygon and Disceus. Proc. Bost. Soc. nat. hist. 19: 197-215. 
Garman, S. W., 1913. The Plagiostomia (sharks, skates and rays). Mem. Mus. Comp. Zool. 36: 1-515, 75 pls.

Günther, A., 1870. Catalogue of fishes in the British Museum. London, 8: $\mathrm{xxv}+549 \mathrm{pp}$.

Günther, A., 1880. A contribution to the knowledge of the fish-fauna of the Rio de la Plata. Ann. Mag. nai. hist. 5(6): 7-15.

d'Orbigny, A., 1834. Voyage dans l'Amérique Méridionale. Trygon histrix, plate 13 (folio). Paris.

Ribeiro, A. de M., 1907. Fauna brasiliense. Peixes II (Desmobranchios). Archos. Mus. nac. Rio de Janeiro 14: 129-217.

Schomburgk, R. H., 1843. Fishes of British Guiana, Part II. In: W. Jardine, Naturalist's Library 40: 129-214, 30 pls. Edinburgh, London.

Vaillant, L., 1880. Sur les raies recueillis dans l'Amazone par M. le Dr. Jobert. Bull. Soc. Philom. Paris, ser. 7, 4: 251-252. 